\title{
The relationship between soldier's body readiness level and the anxiousness tendency of students in the flyer academy of the Indonesian Air Force Army Adisutjipto Airbase Yogyakarta
}

\author{
Wahyudi**, Cecep Sugeng Kristanto², Sumarni DW². \\ ${ }^{1}$ Ranai Airbase Hospital, Natuna District, Riau Province, ${ }^{2}$ Department of Psychiatry, \\ Faculty of Medicine, Universitas Gadjah Mada, Yogyakarta, Indonesia
}

\section{ABSTRACT}

Training the Indonesian Air Force flyers takes a lot of time and fund. The cramped training schedule, demand of discipline and achievement, and intense stress from the fear of dying from plane accidents give the flyer students an even bigger stress that could potentially lead to anxiousness. In the selection of flyer candidates in the field, the most important aspect to be noticed is the body readiness of the candidates, whereas the mental health is frequently left unchecked. There was a case in a training session where a flyer student experienced a bad mental and academic achievement that, after being traced, resulted from poor mental health test, although the military body readiness test was good. It left the country with a loss from having to discharge the student. The aim of this study was to identify the relationship between the military body readiness level and the anxiousness tendency of a flyer apprentice. This was an observational study with cross-sectional design. The research subjects was the flyer students of the Indonesian National Air Force Army in Adisutjipto Airbase Yogyakarta. The sample was taken from all of the subjects which fulfilled the inclusion and exclusion criteria. The measurement of the anxiousness used the TMAS (Taylor Manifest Anxiety Scale), whereas the military body readiness value was taken directly in the field test. Moreover, psychological stress was also measured using Instrument of Psychosocial Stressor Assessment (IPSP). The results were analyzed using Chi-Square test and multiple regression analysis. It was found that there was no significantly relationship between the military body readiness value and the anxiousness tendency of the flyer student in the flyer academy of the Indonesian National Air Force Army in Adisutjipto Airbase Yogyakarta $(p>0,05)$. The psychological stress factor has a role in creating the anxiousness tendency of the flyer students.

\section{ABSTRAK}

Untuk menghasilkan seorang penerbang TNI Angkatan Udara dibutuhkan waktu yang panjang dan biaya yang banyak. Bentuk tekanan, disiplin, pendidikan yang keras dan ketat bagi seorang penerbang selama menempuh pendidikan merupakan keadaan berat yang dialami oleh seorang penerbang. Padatnya jadwal kegiatan pendidikan, tuntutan prestasi, stresor yang berat karena berisiko kematian bila terjadi kecelakaan pesawat, membuat siswa penerbang terpapar tekanan yang lebih kuat sehingga berpotensi mengalami kecemasan. Dalam kenyataan di lapangan, pada saat seleksi calon penerbang TNI Angkatan Udara, hasil test kesamaptaan jasmani lebih diutamakan, sedangkan test kesehatan jiwa seringkali kurang diperhatikan. Hal ini disebabkan di

\footnotetext{
* corresponding author: wahyudi_au@yahoo.com
} 


\begin{abstract}
kalangan TNI Angkatan Udara sampai saat ini masih banyak yang berpendapat bahwa seorang militer yang tes kesamaptaan jasmani militernya baik, maka hasil kesehatan jiwanya pasti tidak ada masalah, sehingga hasil test kesehatan jiwa sering diabaikan. Padahal beberapa kasus terjadi, saat menjalani pendidikan penerbang, seorang siswa penerbang mengalami masalah prestasi akademik dan mental yang jelek. Setelah ditelusuri, ternyata hasil tes kesamaptaan jasmani militernya memang baik, tetapi hasil test kesehatan jiwanya buruk. Akibatnya negara mengalami kerugian karena harus memecat siswa penerbang yang bermasalah tersebut. Tujuan penelitian ini adalah untuk mengetahui hubungan antara tingkat kesamaptaan jasmani militer terhadap kecenderungan cemas pada siswa penerbang. Penelitian ini merupakan penelitian observasional menggunakan rancangan cross-sectional. Subjek penelitian ini adalah siswa penerbang di sekolah penerbang TNI Angkatan Udara Lanud Adisutjipto Yogyakarta. Sampel diambil dari seluruh populasi yang memenuhi kriteria inklusi. Pengukuran cemas menggunakan TMAS (Taylor Manifest Anxiety Scale), sedangkan nilai kesamaptaan jasmani militer diambil secara langsung melalui test di lapangan. Selain itu tekanan psikososial juga diukur dengan Instrument of Psychosocial Stressor Assessment (IPSP). Uji analisis statistik yang digunakan adalah tes Chi-square dan analisis multiple regresi. Tidak terdapat hubungan bermakna antara nilai kesamaptaan jasmani militer terhadap kecenderungan cemas pada siswa penerbang di sekolah penerbang TNI Angkatan Udara Lanud Adisutjipto Yogyakarta $(p>0,05)$. Faktor tekanan psikososial berperan dalam munculnya kecenderungan cemas pada siswa penerbang.
\end{abstract}

Keywords: military body readiness - flyer apprentice - anxiousness - air force army - stress

\section{INTRODUCTION}

As an integral part of the entire TNI forces, the Indonesian National Air Force Army has main equipments and weaponry system including aircraft, guided missile, radar and the likes of them with other types and capability. ${ }^{1-3}$ To do an air operation duty, it is essential to have a flyer personnel who has, not only a good knowledge, capability, and physical condition, but also an excellent mental health. . $^{4-6}$

There was an assumption among the Indonesian National Air Force Army that mental health test was less needed than the physical health test (military body readiness). In the final test, it is occasionally concluded that when the military body readiness test result is good, the mental health test result is considered good as well. Even though the mental health test result is bad, if the military body test result is good, the candidates are often considered passing the test. It was thought that the poor mental health can be improved during the military education process.

However, there were already some incidents that involved both poor academic achievement and mental behavior during the training, which after being investigated, were caused by the fact that the mental health test was off procedure (the mental health test result could not be evaluated/ failed but passed). In the test curriculum of the pilot apprentice requirements, the mental health test is not even done properly. The test is only a soft and rude motorist psycho test done by a psychologist team without involving psychiatrists. ${ }^{7,8}$ Moreover, the mental health test used is the first mental health test result when entering the military which was done several years before. ${ }^{9-11}$

The objective of this research is to identify the relationship between a soldier's bodily readiness levels toward the anxiousness tendency of an air force flyer apprentice in the flyer academy of Indonesian Air Force Army Adisutjipto Airbase Yogyakarta.

\section{MATERIALS AND METHODS}

\section{Subjects}

This was an observational study using a cross sectional design involving all students in the flyer academy of Indonesian Air Force Army 
Adisutjipto Airbase Yogyakarta conducted in June 2011. Forty-three students consisting of 27 students of branches of elementary flyer school (Sekolah Penerbang/SIP) and 16 students of flyer instructor school (Sekolah Instruktur Penerbang/SEKBANG) who fulfilled the inclusion and exclusion criteria involved in this study. The inclusion criteria was student in the flyer academy who willing to fill and signed an informed consent, while the exclusion criteria was student who suffering from illness. This study has been approved by the Medical and Health Research Ethics Committee, Faculty of Medicine, Universitas Gadjah Mada, Yogyakarta.

\section{Data collection}

Study was conducted by a phsychiatric, a phsychologist and research assistants. On the day that has been aggreed, subjects were gathered to be selected. An explanation concerning the background, objectives, benefit of the study was informed. Subjects who fulfilled the inclusion and exclusion criteria were given an informed consent to be signed. Subjects were also given a questionnaire which consisting characteristics of subjects to be filled. Independent and dependent variables were then taken from each subjects. The independent variable of this study was soldiers' bodily readiness levels, whereas dependent variable was anxiousness score. Soldiers's bodily readness levels were assessed directly through the field test according to technical guidances from Indonesian Air Force Army. ${ }^{1,2}$ Anxiousness level of subjects was measured using Taylor Manifest Anxiety Scale (TMAS) ${ }^{13}$ Phsycosocial stressor as one of the risk factors (moderator variable) of anxiousness was measured using Instrument of Psychosocial Stressor Assessment (IPSP). ${ }^{12}$

\section{Statistical analysis}

Descriptive statistics were used to analyze the characteristics of subjects. Bivariate analysis using Chi-square test was used to evaluate the relationship between between soldiers' bodily readiness levels and the anxiousness tendency, whereas multivariate analysis using logistic regression test was used to analyze correlation among all variables to the anxiousness tendency.

\section{RESULTS}

Forty-three eligible subjects consisting of 27 students of branches of elementary flyer school and 16 students of flyer instructor students were involved in this study. The characteritics of subjects are presented in TABLE 1. Subjects experiencing anxiousness tendency were mostly in the age group of less than 30 years old (37.2\%). The subjects who had official time less than 8 years also experienced anxiousness (37.2\%). The groups of subjects who had greater anxiousness tendency were the SEKBANG students (37.2\%), subjects with singles of marrital status (39.5\%), subjects with difficult stressor $(22 \%)$, and those with a good readiness level (46.5\%). 
TABLE 1. Characteristics of subjects

\begin{tabular}{lcccc}
\hline \multirow{2}{*}{ Variables } & \multicolumn{2}{c}{ Anxious } & \multicolumn{2}{c}{ Not anxious } \\
\cline { 2 - 5 } & $\mathrm{n}=22$ & $\%$ & $\mathrm{n}=22$ & $\%$ \\
\hline Agc (ycar) & 16 & 37.2 & 11 & 25.6 \\
- $\quad$ =30 & 6 & 14.0 & 10 & 23.3 \\
Position & & & & \\
- Lieutenant & 16 & 37.2 & 11 & 25.6 \\
- Captain & 6 & 14.0 & 10 & 23.3 \\
Official time (year) & & & & \\
- <8 & 16 & 37.2 & 11 & 25.6 \\
- $=8$ & 6 & 14.0 & 10 & 23.3 \\
Students' status * & & & & \\
- SEKBANG & 16 & 37.2 & 11 & 25.6 \\
- SIP & 6 & 14.0 & 10 & 23.3 \\
Marrital status & & & & \\
- Single & 17 & 39.5 & 11 & 25.6 \\
- Married & 5 & 11.6 & 10 & 23.3 \\
Rcadincss & & & & \\
- Adequate & 2 & 4.7 & 2 & 4.7 \\
- Good & 20 & 46.5 & 19 & 44.2 \\
Psychosocial stressor & & & & \\
- Easy & 0 & 0 & 20 & 46.5 \\
- Difficult & 22 & 22 & 1 & 2.3 \\
\hline
\end{tabular}

* SEKBANG: students of branches of elementary flyer school; SIP: students of flyer instructor school

The relationship of military body readiness level and the anxiousness tendency can be seen in TABLE 2. It was found that among four subjects having adequate military body readiness level, two subjects $(50 \%)$ did not have anxiousness tendency and the other two
(50\%) had anxiousness tendency. In addition, among 39 subjects having good military body readiness level, 19 subjects $(48.6 \%)$ did not anxiousness tendency and 20 subjects (51.4\%) had anxiousness tendency

TABLE 2. Relationship between military body readiness level and the anxiousness tendency

\begin{tabular}{lcccccc}
\hline & \multicolumn{2}{c}{ No } & \multicolumn{2}{c}{ Yes } & \multicolumn{2}{c}{ Total } \\
\cline { 2 - 7 } Readiness & $\mathrm{f}$ & $\%$ & $\mathrm{f}$ & $\%$ & $\mathrm{f}$ & $\%$ \\
\hline Adequate & 2 & 50.0 & 2 & 50.0 & 4 & 100 \\
Good & 19 & 48.6 & 20 & 51.4 & 39 & 100 \\
\hline
\end{tabular}

${ }^{*} \mathrm{X}^{2}=0.004 ; \mathrm{df}=0.961(\mathrm{p}>0.05) ; \mathrm{c}=0.007$ 
Statistical analysis found that no significantly relationship between military body readiness level and anxiousness tendency of subjects $\left(\mathrm{X}^{2}=0.004 ; \mathrm{df}=0.961 \quad(\mathrm{p}>0.05)\right.$; $\mathrm{c}=0.007)$. It was indicated that subjects who had a good body readiness level did not gauarantee to be resistant to anxiousness.

Further statistical analysis using bivariate analysis showed that among risk factors affecting the anxiousness tendency (TABLE 3), only psychosocial stressor that had a significantly relationship with the anxiousness tendency $(\mathrm{p}<0.05)$. Other risk factors including marrital status, age, position, official time, students' status, and body readiness had no a significantly relationship with the anxiousness tendency $(\mathrm{p}>0.05)$.

TABLE 3. Bivariate analysis of the variables which affect the anxiousness tendency

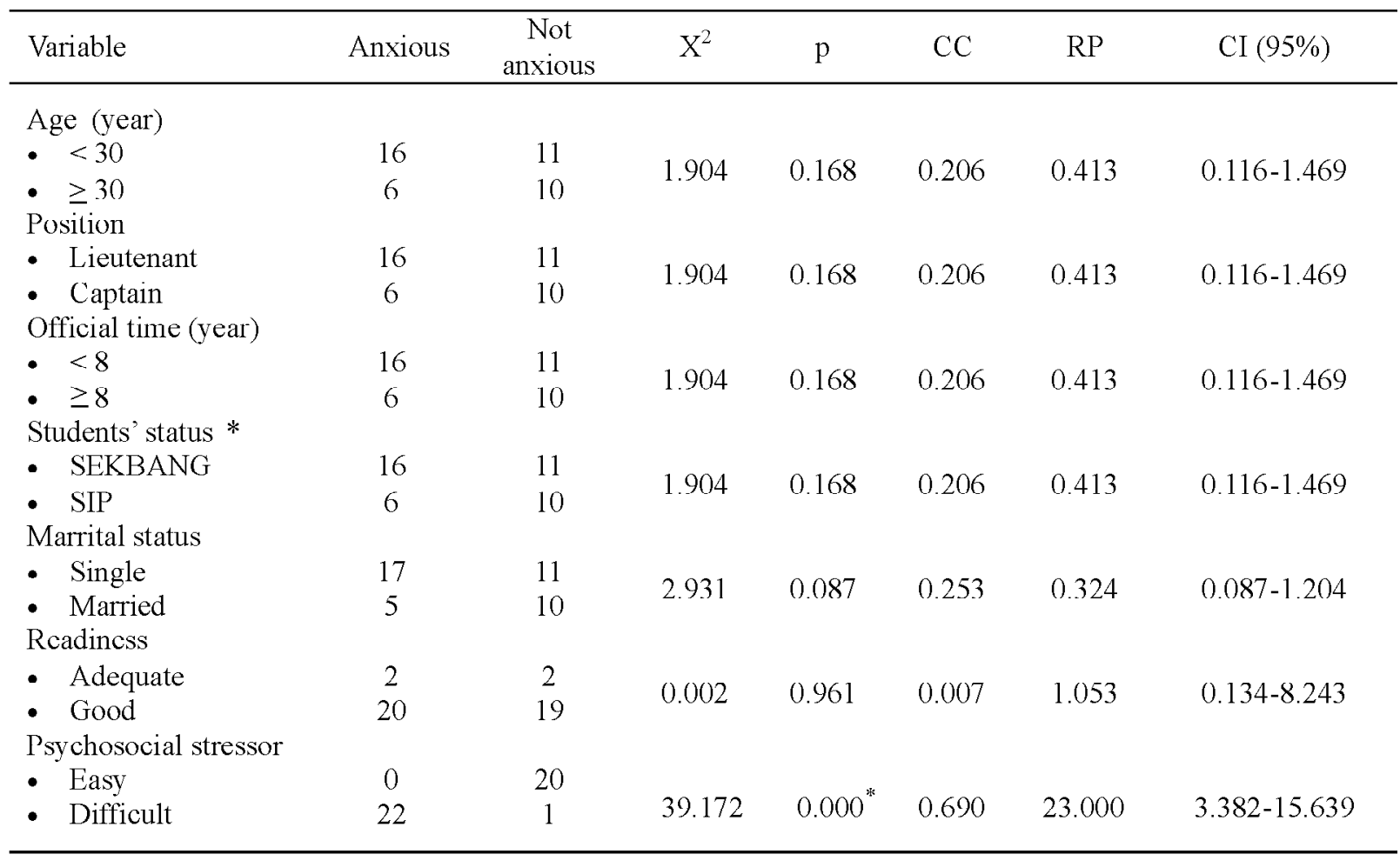

Multivariate analysis (TABLE 4) also showed that only psychosocial stressor that had a significantly relationship with the anxiousness tendency $(\mathrm{p}<0.05)$, whereas age, position, official time, students' status, marrital status, and readiness had no a significantly relationship with the anxiousness tendency $(\mathrm{p}>0.05)$. 
TABLE 4. Multivariate analysis of variables which affect the anxiousness tendency

\begin{tabular}{|c|c|c|c|c|c|c|c|c|}
\hline \multirow{2}{*}{ Variable } & \multirow{2}{*}{$\beta$} & \multirow{2}{*}{$\mathrm{SE}$} & \multirow{2}{*}{ Wald } & \multirow{2}{*}{$\mathrm{df}$} & \multirow{2}{*}{$\mathrm{p}$} & \multirow{2}{*}{$\operatorname{Exp}(\beta)$} & \multicolumn{2}{|c|}{$95 \% \mathrm{CI}$} \\
\hline & & & & & & & Lower & Upper \\
\hline Age & 3.455 & 10.754 & 0.103 & 1 & 0.748 & 31.653 & 0.000 & 4.507 \\
\hline Position & -0.948 & 18.003 & 0.003 & 1 & 0.958 & 0.388 & 0.000 & 8.183 \\
\hline Official time & -0.744 & 2.780 & 0.072 & 1 & 0.789 & 0.475 & 0.002 & 1.100 \\
\hline Students' status & -7.254 & 8.008 & 0.820 & 1 & 0.365 & 0.001 & 0.000 & 4.637 \\
\hline Marrital status & -2.513 & 10.892 & 0.053 & 1 & 0.818 & 0.081 & 0.000 & 1.514 \\
\hline Readiness & 1.031 & 0.651 & 2.508 & 1 & 0.113 & 2.803 & 0.783 & 1.000 \\
\hline $\begin{array}{l}\text { Psychosocial } \\
\text { stressor }\end{array}$ & 3.460 & 22.319 & 0.024 & 1 & 0.020 & 31.821 & 0.000 & 4.507 \\
\hline
\end{tabular}

The influence of psychosocial stressor to the anxiousness tendency was then analyzed using logistic regression analysis (TABLE 5). The result showed that a significant relationship between phsychosocial with the anxiousnees tendency for flyer students was observed in this study $(\mathrm{p}<0.05)$.

TABLE 5. Logistic regression influence of psychosocial stressor to the anxiousness tendency

\begin{tabular}{lccccccccc}
\hline Variable & $\beta$ & SE & Wald & df & p & Exp $(\beta)$ & \multicolumn{2}{c}{$95 \%$ CI } \\
\hline $\begin{array}{l}\text { Psychosocial } \\
\text { stressor }\end{array}$ & 0.930 & 0.503 & 3.415 & 1 & 0.017 & 2.534 & 0.945 & 6.792 \\
\hline
\end{tabular}

\section{DISCUSSION}

This study showed no significantly relationship between military body readiness level with anxiousness tendency in flyer students. Anxiousness is one of mental or psychological causes of stress which is body's response to physical, mental or emotional changes situation and forces. Anxiousness is influenced by several factors e.g. maturity, body readiness, education, personality, socio-cultural and environmental. ${ }^{14}$ This study indicated that military body readiness did not influence anxiousness tendency of students in the flyer academy of Indonesian Air Force Army. The study conducted on students of Indonesian Army also showed that there is no relationship between military body readiness and anxiousness tendency. ${ }^{15}$ Therefore, it was can be stated that having a good body readiness level only does not guarantee someone to be resistant to anxiousness. Other factors such as maturity, education, personality, socio-cultural and environmental may also play an important role in the occurance of anxiousness.

Risk factors of anxiousness evaluated in this study including marrital status, age, position, official time, students' status, and body 
readiness had no a significantly relationship with the anxiousness tendency. This result is in accordance with other study conducted by Chritianty. ${ }^{15}$ However, psychosocial stressor evaluated in this study had a significantly relationship with the anxiousness tendency. It is indicated that psychosocial stressor becomes significant risk factor of the occurance of anxiousness of students in the flyer academy of Indonesian Air Force Army. This result is suported by Romadhon ${ }^{16}$ and Ditjed Yanmed. ${ }^{17}$

\section{CONCLUSION}

It can be concluded that there was no relation between military body readiness level with anxiousness tendency in the flyer academy of Indonesian Air Force Army Adisutjipto Airbase Yogyakarta. It is suggested that upon accepting flyer apprentices, the Admiralty of Indonesian Air Force Army should not only base the selection on psychology test but also includes the intervention of psychiatry test.

\section{ACKNOWLEDGEMENTS}

We would like to thank all students in the flyer academy of Indonesian Air Force Army Adisutjipto Airbase Yogyakarta who willing to participate in this study.

\section{REFERENCES}

1. TNI Markas Besar Angkatan Udara. Buku petunjuk teknis TNI AU tentang uji kesamaptaan jasmani. Jakarta: TNI Angkatan Udara, 2003.

2. TNI Markas Besar Angkatan Udara. Buku petunjuk teknis TNI AU tentang latihan kesamaptaan jasmani penerbang. Jakarta: TNI Angkatan Udara, 2004.

3. TNI AU Komando Pendidikan. Buku petunjuk teknis TNI AU tentang evaluasi hasil belajar siswa. Jakarta: TNI Angkatan Udara, 2006.

4. TNI Markas Besar. Buku petunjuk teknis pemeriksaan dan uji kesamaptaan jasmani calon Perwira TNI. Jakarta: Tentara Nasional Indonesia, 1999.
5. TNI AU Komando Pendidikan. Petunjuk teknis pendidikan tentang kriteria penilaian terbang dengan pesawat AS 202. Jakarta: TNI Angkatan Udara, 1987.

6. TNI Markas Besar Angkatan Udara. Buku petunjuk teknis TNI AU tentang pembinaan jasmani. Jakarta: TNI Angkatan Udara, 2002.

7. TNI AU Komando Pendidikan. Kurikulum pendidikan Sekolah Instruktur Penerbang TNI (SIP). Jakarta: TNI Angkatan Udara, 2004.

8. TNI Markas Besar Angkatan Udara. Kurikulum pendidikan Sekolah Instruktur Penerbang (SIP) dengan pesawat AS-202 Bravo. Jakarta: TNI Angkatan Udara, 2002.

9. TNI Markas Besar Angkatan Udara. Kurikulum pendidikan Sekolah Dasar Kecabangan Penerbang (Dua Tipe Pesawat). Jakarta: TNI Angkatan Udara, 2009.

10. TNI Markas Besar Angkatan Udara. Kurikulum pendidikan Sekolah Instruktur Penerbang (SIP). Jakarta: TNI Angkatan Udara, 2010.

11. TNI Markas Besar. Kurikulum pendidikan Sekolah Instruktur Penerbang TNI (SIP). Jakarta: Tentara Nasional Indonesia, 2008.

12. Sudiyanto, A. Pengaruh pendidikan kesehatan jiwa keluarga terhadap kekambuhan penderita gangguan afektif berat [Disertasi]. Yogyakarta: Univeristas Gadjah Mada, 1998.

13. Wicaksono, I. Ansietas pada wartawan anggota PWI Cabang Yogyakarta, uji validitas dan realibilitas instrumen Tylor Manifest Anxiety Scale (TMAS), penentuan frekuensi ansietas dan faktor-faktor yang mempengaruhi serta hubungan dengan motif berprestasi. Jiwa 1992; XXXIII, 4 (1993): 85-114.

14. Hawari D. Manajemen stres, cemas dan depresi. Edisi 2. Jakarta: Universitas Indonesia, 2008.

15. Chritianty L. Hubungan antara kecemasan dengan nilai Samapta pada siswa SECAPAAD yang sedang melaksanakan pendidikan perwira di SECAPAAD. Bandung: Bagian Psikiatri Fakultas Kedokteran UNPAD/RS Hasan Sadikin, 2010.

16. Romadhon. Gambaran klinik dan psikofarmaka pada penderita gangguan kecemasan. [cited Avril 20, 2008]. Available from: http://www.kalbe.co.id/ files/cdk/09/

17. Ditjen Yanmed. Pedoman penggolongan gangguan jiwa Indonesia. Edisi 2. Jakarta: Diskeswa, Departemen Kesehatan Republik Indonesia, 1985. 